\title{
Animal Models of Hydrocephalus
}

\author{
Domenico L. Di Curzio1,2 \\ ${ }^{1}$ Department of Medical Microbiology, University of Manitoba, Winnipeg, Canada \\ ${ }^{2}$ Department of Pathology, University of Manitoba, Children's Hospital Research Institute of Manitoba, Winnipeg, Canada \\ Email: umdicurd@myumanitoba.ca
}

How to cite this paper: Di Curzio, D.L. (2018) Animal Models of Hydrocephalus. Open Journal of Modern Neurosurgery, 8 , $57-71$.

https://doi.org/10.4236/ojmn.2018.81004

Received: October 17, 2017

Accepted: December 24, 2017

Published: December 27, 2017

Copyright $\odot 2018$ by author and Scientific Research Publishing Inc. This work is licensed under the Creative Commons Attribution International License (CC BY 4.0).

http://creativecommons.org/licenses/by/4.0/ (c) (i) Open Access

\begin{abstract}
Hydrocephalus is a neurological condition characterized by altered cerebrospinal fluid (CSF) flow leading to an accumulation of CSF inside the cranial vault. Neuropathogenesis associated with hydrocephalus has been elucidated by pathological studies of human brains and through experimental and genetic animal models. Experimental animal models have been developed in numerous species using a variety of methods and agents to induce hydrocephalus or through genetic mutations in rodents. Each of these animal models has been described briefly in this review, along with the basic strengths and weaknesses of each model. Although none of these models can fully mimic the human condition, they each provide fundamental knowledge contributing to understanding more about the pathogenesis of hydrocephalus and its underlying causes.
\end{abstract}

\section{Keywords}

Hydrocephalus, Animal Models, Kaolin, Mechanical, Genetic

\section{Introduction}

The pathogenesis of brain damage in hydrocephalus has been elucidated by pathological studies of human brains and through the use of experimental animal models. Experimental animal models have been developed in a range of species using a variety of methods to induce hydrocephalus or through genetic mutations in rodents. These models have been assessed in different reviews [1]-[6]. The following discussion will briefly describe each of the experimental models, along with the basic advantages and disadvantages of each model. Although none of these models can fully mimic the human condition, they each provide important contributions of understanding more about the pathogenesis of hydrocephalus and how to potentially treat it effectively. 


\section{Kaolin Injection}

The most common method of inducing experimental hydrocephalus is the intracisternal kaolin injection model [1]. This model was introduced in the 1930s [7] [8]. A dose of $0.01-0.2 \mathrm{~mL}$ of $20 \%-25 \%$ suspension of kaolin clay (aluminum silicate) is injected into the cisterna magna either through surgical exposure of the cistern and brainstem or by inserting a needle tip percutaneously. Kaolin deposited at the base of the fourth ventricle spreads in the subarachnoid space, where it induces an inflammatory reaction and fibrous scarring in the meninges. This resembles the scarring that develops following meningitis or hemorrhage and leads to an obstruction of the CSF pathways close to the fourth ventricle apertures and ventricular enlargement ensues [4] [5] [7] [9]. The species that have been examined include mice [10] [11], rats [12] [13] [14] [15] [16], guinea pigs [17] [18] [19], rabbits [20], cats [8] [21] [22] [23], ferrets [24] [25], dogs [9] [26] [27] [28], pigs [29], sheep [30] [31] [32], and monkeys [30] [32]. The main disadvantage of kaolin induction is that the inflammatory reaction, composed of macrophages and CD4- and CD8-positive lymphocytes [33], might confound interpretation of microglial reactions in these animal models. Second, if performing the percutaneous needle injection method, it is possible to cause damage by accidental punctures into brainstem structures, particularly in neonatal animals. Third, although the dose and concentration of kaolin injected likely play a role in the rate of ventriculomegaly and pathology, age of the animal and mode of inducing hydrocephalus, whether using kaolin or otherwise, are important factors in hydrocephalic pathological outcomes [3] [24] [34]. Even when using the same dose and concentration, there is variable dispersion of kaolin in the subarachnoid space, and this may account for the relatively unpredictable rate and magnitude of ventricular dilatation that transpires. However, these are outweighed by the practical matter that the kaolin model is a simple, inexpensive, and consistent way of inducing hydrocephalus in experimental animals [5] [34].

\section{Silicone Oil Injection}

Another method of inducing hydrocephalus in animal models is through an intracisternal injection of viscous silicone oil. This creates a purely mechanical obstruction for the outflow of CSF from the fourth ventricle to the subarachnoid space [20] [35]. The method has also been successfully used in a few animal species including rats [36], rabbits [37] [38] [39] [40] [41], and dogs [35] [42] [43]. The silicone oil used in this model is apparently an inert substance, so it does not produce the same inflammation of the meninges and scarring that kaolin induces [35] [41] [42]. It should be noted though that silicone oils do lead to some intraocular inflammatory response when used in the treatment of retinal detachment [44], but it is not certain how this translates to the brain. Like kaolin, the silicone oil model is easy and inexpensive to perform [1] [5]; however, it does not produce severe ventricular expansion or sustained elevated intracranial 
pressure [1] [5] [39], and thus, it is not an effective model of chronic infantile hydrocephalus. Some studies used a silastic elastomer solution that hardens quickly to improve the rate of ventriculomegaly attained [45] [46].

\section{Mechanical Obstructions and Toxins}

Over the $20^{\text {th }}$ and $21^{\text {st }}$ centuries, various other substances/agents have been used to induce hydrocephalus by implanting a mechanical plug that leads to hydrocephalus. Some of these substances include cotton or cellophane cylinders implanted in the cerebral aqueduct of adult dogs [9] [47] [48]; India ink [49], small pieces of laminalia [6], and cyanoacrylate glue [50] [51] among others. These substances will typically cause an obstructive form of hydrocephalus either by blocking the fourth ventricle and/or access to the subarachnoid space through the apertures or by inducing aqueductal stenosis, which will in turn lead to ventriculomegaly. Cotton and cellophane plugs have successfully induced hydrocephalus in large animals, but they involve an invasive, major surgical procedure that likely damages brainstem structures, so they should only be limited to acute experiments [5]. Cyanoacrylate glue also induces obstructive hydrocephalus in the fourth ventricle, where it quickly cures, and this potentially prevents CSF leakage by adhering to the ependymal and pial layers of the brainstem and cerebellum without distorting surrounding brain tissues [5]. It has been shown to work in large animals (i.e., dogs) with gyrencephalic brains, like humans, but it is also expensive and involves a complicated technical procedure that has not always worked in other animal models [1] [5] [52]. Another issue is that these mechanical obstructions limit the experiments to have an acute nature, and thus may only represent trauma-induced clinical hydrocephalus in humans but not progressive forms of the condition. An additional implantation method is balloon insertion in the ventricles of lambs [53] [54] [55]. Unlike the other techniques described above, the balloon implantation method induces a form of communicating or non-obstructive hydrocephalus because there is no point of obstruction and does not change the mean CSF pressure [53] [54] [55]. However, it elevates the pulse wave of the CSF in the ventricles [56], which could have other implications.

Different toxins have been administered or fed to pregnant rats, which successfully produced hydrocephalic offspring. Some of these substances include trypan blue [57] and tellurium [58] [59] [60]. These substances will lead to obstructive hydrocephalus by blocking the cerebral aqueduct or by closure of the subarachnoid space, and ventricular enlargement will follow in these rats. Unfortunately, these toxins likely cause brain damage or alter normal developmental sequences to induce congenital defects that subsequently lead to ventriculomegaly, and often death will occur by the end of the second week of life [59] [61].

\section{Molecular Fibrosis Manipulation}

Molecular agents associated with the fibrotic pathway have also been injected or 
overexpressed in animal models to induce obstructive hydrocephalus. Basic fibroblast growth factor (FGF-2) [62] [63] has been injected/implanted in the cisterna magna of rats, rabbit, dogs, and/or marmosets. Intrathecal injection or transgenic overexpression of transforming growth factor-beta 1 (TGF- $\beta 1$ ) has also successfully induced hydrocephalus in mice [64] [65] [66] [67] [68]. Basic FGF-2 and TGF- $\beta 1$ injections are relatively easy procedures that both presumably create a fibrotic obstruction in the subarachnoid space [1] [5] [66] [69], but they are expensive procedures that might have a direct impact on different brain cells, including synapse formation and neuronal migration [1] [70] [71].

\section{Blood and Blood-Related Injections}

More recently, several studies have established rodent models of post-hemorrhagic hydrocephalus through intraventricular injection of blood directly into the lateral ventricles of rats [72] [73] [74]. Other studies have successfully performed the same intraventricular injection(s) with substances found in blood serum and/or plasma either alone or in conjunction with blood itself, including thrombin [75] [76] and $\mathrm{FeCl}_{3}$ [77] [78] in rats, along with lysophosphatidic acid (LPA) in mice [79]. All of these studies have also examined non-surgical therapeutic agents to treat the experimental hydrocephalus with varied efficacy, which sheds more light on the neuropathology associated with hydrocephalus along with the potential neuroprotective effects of various pharmacological treatments. In addition, some of these models, such as the LPA model in mice [79], resemble different human fetal forms of the hydrocephalus caused by hemorrhage [80] [81]. However, blood-brain-barrier disruption could occur using these models [75], and hemorrhage is only one of the many causes of hydrocephalus. In addition, it is important to examine these blood injection models further without therapeutic intervention to learn more about the neuropathology associated with chronic hydrocephalus.

\section{Genetic Models}

In humans, hydrocephalus manifests due to a variety of causes and can occur across the lifespan or be present at birth. Congenital hydrocephalus can be linked to genetic causes, yet until recently, there were only a few genes linked to the condition, including the X-linked L1 cell adhesion molecule (L1CAM) [82]. This recent study has shown that there may be increased genetic heterogeneity associated with hydrocephalus. There are also genetic models of hydrocephalus that have been discovered and studied over the last century, but very few are linked to the same genes as humans. The genetic models include the hydrocephalus Texas (H-Tx) rat, the LEW/Jms rat, the L1CAM mutant mouse model, the hydrocephalus-3 (hy-3) mouse, the hydrocephalus with hop gait (hyh) mouse, the SUMS/NP mouse, the hpy mouse, and a double transgenic mouse model, among others. The hydrocephalic H-Tx rat is a spontaneous neonatal hydrocephalus model that develops aqueductal stenosis and ventricular 
enlargement beginning at approximately 18 days gestation [83] [84], while the LEW/Jms rat strain came from an inbred strain of Wistar-Lewis rats that exhibit a similar onset and pathophysiology to the H-Tx rat [85] [86]. The H-Tx rat has been studied extensively and displays adverse effects in the germinal epithelium (GE) including reduced cell proliferation, impaired cell cycling, and/or increased cell death and arrested migration of glial cells from the GE into the cerebrum, which are hypothesized to be associated with impaired signalling molecules carried by the CSF [87]-[93]. Its phenotypic characterization is predictable, and surgical intervention can treat this inherited form of hydrocephalus [5] [94]. Additionally, research is uncovering the potential roles that folate imbalance plays in the defects associated with the early-onset of hydrocephalus, where maternal administration of folic acid increases the incidence of hydrocephalus, while combined folinic acid and tetrahydrofolate decrease the incidence [95]. Despite these breakthroughs, the underlying genetic cause of this partially penetrant disorder is still unknown [96] [97] [98], which raises issues about its applicability. There is also concern that there are potential brain abnormalities in nonhydrocephalic "normal" H-Tx rats because they perform worse than SpragueDawley rats on behavioural tests [99]. It is also expensive to maintain the breeding colony for these rats [1] [5].

As indicated, there are also spontaneous mutant mice that exhibit a hydrocephalic phenotype. The L1 CAM mutant mouse often displays ventricular expansion, cerebral cortex pyramidal neuron defects, and shrunken hippocampus, corticospinal tract, and corpus callosum [100] [101]. Meanwhile, the hy-3 mouse was initially discovered in the 1940s and was suspected to be the result of a pleiotropic gene [102]. Research in this model continued in the 1960s and 1970s, where the inheritance and pathogenesis were investigated, which revealed impairment to the choroid plexus and ependymal layer [103] [104]. However, it was not until 2003 that the discovery of the autosomal-recessive frameshift mutation in the Hydin gene caused this lethal form of perinatal onset communicating hydrocephalus [105], which may manifest due to impairment of ependymal ciliary motility [106]. With further understanding of the genetic cause of hy-3, it is becoming more feasible to investigate this model further. However, like the $\mathrm{H}-\mathrm{Tx}$ rat, it is expensive to maintain the breeding colony [1] [5]. Another mutant model is the hyh hydrocephalic mouse that is associated with a domed head, appreciably reduced cerebral cortex, and a lack of communication between the caudal aqueduct and fourth ventricle, which subsequently leads to ventricular enlargement that is typically lethal between a few weeks to 2 months of age [107]. However, the hyh mouse is a complex genetic model involving a hypomorphic missense mutation of the soluble $\mathrm{N}$-ethylmalemide-sensitive factor (NSF) attachment protein alpha-S-nitroso-N-acetylpenicillamine (Napa $\alpha$-SNAP) gene mapped to the proximal end of chromosome 7 , which is associated with mRNA instability [107] [108] [109]. This is believed to disturb neural cell determination by disrupting cortical progenitor pools and laminar organization, as well as the localization of several apical proteins implicated in regulating neural 
cell fate. It has other effects on cell processes including disorganization and reduction of both proliferative and neural progenitor cells (NPCs) in the subventricular zone (SVZ) [110], but the cause of these effects is not clearly understood. It also displays the hop gait phenotype, which is not necessarily associated with hydrocephalus. In addition, mutant mouse models are too small for surgical interventions, and thus, there are concerns about their applicability to the human situation [5].

The SUMS/NP mouse is an inbred strain involving a recessive gene that is likely autosomal and develops congenital hydrocephalus with ventricle enlargement around E16 but is explicitly visible by P3-P4 in about 13\% of matings between heterozygous parents [111] [112]. These animals develop progressively severe hydrocephalus with expanded lateral and third ventricles and reduced or absent cerebral aqueduct, and they die shortly after weaning. The hydrocephalus associated with polydactyly (hpy) mice involves a recessive mutation on chromosome 6 where homozygous mice exhibit a hopping gait, male sterility, scoliosis, and develop non-obstructive hydrocephalus postnatally around P6 and most die by P14 [113] [114] [115]. The hpy mice were also originally observed as offspring of X-irradiated mice [114] [116], but the specific factors associated with hydrocephalus development are unknown [117]. The unique double transgenic mouse model of communicating hydrocephalus shows severe ventricular enlargement and ependymal denudation and can be induced at any age because of doxycycline, which binds to tet-transactivator (tTA) and regulates astrocyte activation [118] [119]. It involves crossing of the G1-coupled Ro1 receptor activated solely by synthetic ligands (RASSL) in astrocytes mouse line with a tTA mouse line that has a fragment of human glial fibrillary acidic protein (GFAP) promoter that enables expression of Ro1 in astrocytes only. Despite the benefits of these mouse models in understanding the neuropathology of hydrocephalus, these models are limited because of the difficulties in incorporating surgical treatment, such as ventricular shunts, primarily due to the small size [120].

\section{Summary}

Researchers have unveiled different spontaneous mutant models of hydrocephalus, while others have induced experimental hydrocephalus using numerous agents with some successfully working in different animal models. All of these studies have imparted important information to understand the causes of and potential treatments for hydrocephalus. Because of them, much has been discovered about the neuropathology of this condition. However, the above discussion has made it evident that none of them are perfect in mimicking the human condition, for which there is still no definitive cure.

\section{References}

[1] Del Bigio, M.R. (2001) Future Directions for Therapy of Childhood Hydrocephalus: A View from the Laboratory. Pediatric Neurosurgery, 34, 172-181. https://doi.org/10.1159/000056016 
[2] Del Bigio, M.R. (2004) Cellular Damage and Prevention in Childhood Hydrocephalus. Brain Pathology, 14, 317-324. https://doi.org/10.1111/j.1750-3639.2004.tb00071.x

[3] Hirayama, A. (1980) Histopathological Study of Congenital and Acquired Experimental Hydrocephalus. Brain \& Development, 2, 171-189. https://doi.org/10.1016/S0387-7604(80)80038-6

[4] Hochwald, G.M. (1985) Animal Models of Hydrocephalus: Recent Developments. Proceedings of the Society for Experimental Biology and Medicine, 178, 1-11. https://doi.org/10.3181/00379727-178-41977

[5] Khan, O.H. and Del Bigio, M.R. (2006) Experimental Models of Hydrocephalus. In: Tatlisumak, T. and Fisher, M., Eds., Handbook of Experimental Neurology: Methods and Techniques in Animal Research, Cambridge University Press, Cambridge, 457-471. https://doi.org/10.1017/CBO9780511541742.026

[6] Matsumoto, S., Hirayama, A., Yamasaki, S., Shirataki, K. and Fujiwara, K. (1975) Comparative Study of Various Models of Experimental Hydrocephalus. Child's Brain, 1, 236-242. https://doi.org/10.1159/000119572

[7] Dixon, W.E. and Heller, H. (1932) Experimentelle hypertonie durch Eröhung des intrakaniellen Druckes. Archiv for Experimentelle Pathologie und Pharmakologie, 166, 265-275. https://doi.org/10.1007/BF01860670

[8] Lindauer, M.A. and Griffith, J.Q. (1938) Cerebrospinal Pressure, Hydrocephalus and Blood Pressure in Cat Following Intracisternal Injection of Colloidal Kaolin. Proceedings of the Society for Experimental Biology and Medicine, 39, 547-549. https://doi.org/10.3181/00379727-39-10268

[9] Schurr, P.H., McLaurin, R.L. and Ingraham, F.D. (1953) Experimental Studies on the Circulation of the Cerebrospinal Fluid and Methods of Producing Communicating Hydrocephalus in the Dog. Journal of Neurosurgery, 10, 515-525. https://doi.org/10.3171/jns.1953.10.5.0515

[10] da Silva Lopes, L., Slobodian, I. and Del Bigio, M.R. (2009) Characterization of Juvenile and Young Adult Mice Following Induction of Hydrocephalus with Kaolin. Experimental Neurology, 219, 187-196. https://doi.org/10.1016/j.expneurol.2009.05.015

[11] Wang, D., Nykanen, M., Yang, N., Winlaw, D., North, K., Verkman, A.S. and Owler, B.K. (2011) Altered Cellular Localization of Aquaporin-1 in Experimental Hydrocephalus in Mice and Reduced Ventriculomegaly In Aquaporin-1 Deficiency. Molecular and Cellular Neuroscience, 46, 318-324. https://doi.org/10.1016/j.mcn.2010.10.003

[12] Del Bigio, M.R., Crook, C.R. and Buist, R. (1997) Magnetic Resonance Imaging and Behavioral Analysis of Immature Rats with Kaolin-Induced Hydrocephalus: Preand Postshunting Observations. Experimental Neurology, 148, 256-264. https://doi.org/10.1006/exnr.1997.6644

[13] Del Bigio, M.R., and Zhang, Y.W. (1998) Cell Death, Axonal Damage, and Cell Birth in the Immature Rat Brain Following Induction of Hydrocephalus. Experimental Neurology, 154, 157-169. https://doi.org/10.1006/exnr.1998.6922

[14] Hochwald, G.M., Boal, R.D., Marlin, A.E. and Kumar, A.J. (1975) Changes in Regional Blood-Flow and Water Content of Brain and Spinal Cord in Acute and Chronic Experimental Hydrocephalus. Developmental Medicine and Child Neurology Supplement, 35, 42-50.

[15] Hochwald, G.M., Nakamura, S. and Camins, M.B. (1981) The Rat in Experimental Obstructive Hydrocephalus. $Z$ Kinderchir, 34, 403-410. 
[16] Li, J., McAllister, J.P., II, Shen, Y., Wagshul, M.E., Miller, J.M., Egnor, M.R., Johnston, M.G., Haacke, E.M. and Walker, M.L. (2008) Communicating Hydrocephalus in Adult Rats with Kaolin Obstruction of the Basal Cisterns or the Cortical Subarachnoid Space. Experimental Neurology, 211, 351-361. https://doi.org/10.1016/j.expneurol.2007.12.030

[17] Madhavi, C. and Jacob, M. (1989) Atypical Cilia in the Choroid Plexus of Guineapig. Indian Journal of Medical Research, 90, 484-489.

[18] Madhavi, C. and Jacob, M. (1990) Morphometry of Choroid Plexus in Hydrocephalic Guineapigs. Indian Journal of Medical Research, 92, 89-94.

[19] Madhavi, C. and Jacob, M. (1992) Morphometry of Mitochondria in the Choroidal Ependyma of Hydrocephalic Guineapigs. Indian Journal of Medical Research, 96, 72-77.

[20] Weller, R.O. and Wisniewski, H. (1969) Histological and Ultrastructural Changes with Experimental Hydrocephalus in Adult Rabbits. Brain Pathology, 92, 819-828. https://doi.org/10.1093/brain/92.4.819

[21] Del Bigio, M.R., da Silva, M.C., Drake, J.M. and Tuor, U.I. (1994) Acute and Chronic Cerebral White Matter Damage in Neonatal Hydrocephalus. Canadian Journal of Neurological Sciences, 21, 299-305. https://doi.org/10.1017/S0317167100040865

[22] Eskandari, R., McAllister, J.P., II, Miller, J.M., Ding, Y., Ham, S.D., Shearer, D.M. and Way, J.S. (2004) Effects of Hydrocephalus and Ventriculoperitoneal Shunt Therapy on Afferent and Efferent Connections in the Feline Sensorimotor Cortex. Journal of Neurosurgery, 101, 196-210.

[23] Hochwald, G.M., Epstein, F., Malhan, C. and Ransohoff, J. (1973) The Relationship of Compensated to Decompensated Hydrocephalus in the Cat. Journal of Neurosurgery, 39, 694-697. https://doi.org/10.3171/jns.1973.39.6.0694

[24] Di Curzio, D.L., Buist, R.J. and Del Bigio, M.R. (2013) Reduced Subventricular Zone Proliferation and White Matter Damage in Juvenile Ferrets with Kaolin-Induced Hydrocephalus. Experimental Neurology, 248, 112-128.

https://doi.org/10.1016/j.expneurol.2013.06.004

[25] Di Curzio, D.L., Turner-Brannen, E., Mao, X. and Del Bigio, M.R. (2016) Magnesium Sulfate Treatment for Juvenile Ferrets Following Induction of Hydrocephalus with Kaolin. Fluids and Barriers of the CNS, 13, 7. https://doi.org/10.1186/s12987-016-0031-4

[26] DeFeo, D.R., Myers, P., Foltz, E.L., Everett, B. and Ramshaw, B. (1979) Histological Examination of Kaolin-Induced Hydrocephalus. Its Implications in the Therapy of Animals with Experimentally Induced Hydrocephalus. Journal of Neurosurgery, 50, 70-74. https://doi.org/10.3171/jns.1979.50.1.0070

[27] Rekate, H.L., Erwood, S., Brodkey, J.A., Chizeck, H.J., Spear, T., Ko, W. and Montague, F. (1985) Etiology of Ventriculomegaly in Choroid Plexus Papilloma. Journal of Pediatric Neurosciences, 12, 196-201. https://doi.org/10.1159/000120250

[28] Weller, R.O., Wisniewski, H., Shulman, K. and Terry, R.D. (1971) Experimental Hydrocephalus in Young Dogs: Histological and Ultrastructural Study of the Brain Tissue Damage. Journal of Neuropathology \& Experimental Neurology, 30, 613-627. https://doi.org/10.1097/00005072-197110000-00006

[29] Jetzki, S., Weinzierl, M., Krause, I., Hahne, S., Rehbaum, H., Kiausch, M., Kozubek, I., Hellenbroich, C., Oertel, M., Walter, M. and Leonhardt, S. (2012) A Multisensor Implant for Continuous Monitoring of Intracranial Pressure Dynamics. IEEE Transactions on Biomedical Circuits and Systems, 6, 356-365. 
https://doi.org/10.1109/TBCAS.2012.2183131

[30] Edwards, M.S., Harrison, M.R., Halks-Miller, M., Nakayama, D.K., Berger, M.S., Glick, P.L. and Chinn, D.H. (1984) Kaolin-Induced Congenital Hydrocephalus in Utero in Fetal Lambs and Rhesus Monkeys. Journal of Neurosurgery, 60, 115-122. https://doi.org/10.3171/jns.1984.60.1.0115

[31] Johnston, M.G., Del Bigio, M.R., Drake, J.M., Armstrong, D., Di Curzio, D.L. and Bertrand, J. (2013) Pre- and Post-Shunting Observations in Adult Sheep with Kaolin-Induced Hydrocephalus. Fluids and Barriers of the CNS, 10, 24. https://doi.org/10.1186/2045-8118-10-24

[32] Nakayama, D.K., Harrison, M.R., Berger, M.S., Chinn, D.H., Halks-Miller, M. and Edwards, M.S. (1983) Correction of Congenital Hydrocephalus in Utero I. The Model: Intracisternal Kaolin Produces Hydrocephalus in Fetal Lambs and Rhesus Monkeys. Journal of Pediatric Surgery, 18, 331-338. https://doi.org/10.1016/S0022-3468(83)80177-8

[33] Shinoda, M. and Olson, L. (1997) Immunological Aspects of Kaolin-Induced Hydrocephalus. International Journal of Neuroscience, 92, 9-28. https://doi.org/10.3109/00207459708986386

[34] Del Bigio, M. (1993) Neuropathological Changes Caused by Hydrocephalus. Acta Neuropathologica, 85, 573-585. https://doi.org/10.1007/BF00334666

[35] James, A.E., Jr and Strecker, E.P. (1973) Use of Silastic to Produce Communicating Hydrocephalus. Investigative Radiology, 8, 105-110.

https://doi.org/10.1097/00004424-197303000-00010

[36] Go, K.G., Stokroos, I., Blaauw, E.H., Zuiderveen, F. and Molenaar, I. (1976) Changes of Ventricular Ependyma and Choroid Plexus in Experimental Hydrocephalus, as Observed by Scanning Electron Microscopy. Acta Neuropathologica, 34, 55-64. https://doi.org/10.1007/BF00684944

[37] Del Bigio, M.R. and Bruni, J.E. (1988a) Changes in Periventricular Vasculature of Rabbit Brain Following Induction of Hydrocephalus and after Shunting. Journal of Neurosurgery, 69, 115-120. https://doi.org/10.3171/jns.1988.69.1.0115

[38] Del Bigio, M.R. and Bruni, J.E. (1988b) Periventricular Pathology in Hydrocephalic Rabbits before and after Shunting. Acta Neuropathologica (BerI), 77, 186-195. https://doi.org/10.1007/BF00687430

[39] Del Bigio, M.R. and Bruni, J.E. (1991) Silicone Oil-Induced Hydrocephalus in the Rabbit. Child s Nervous System, 7, 79-84. https://doi.org/10.1007/BF00247861

[40] Page, R.B. (1975) Scanning Electron Microscopy of the Ventricular System in Normal and Hydrocephalic Rabbits. Preliminary Report and Atlas. Journal of Neurosurgery, 42, 646-664. https://doi.org/10.3171/jns.1975.42.6.0646

[41] Wisniewski, H., Weller, R.O. and Terry, R.D. (1969) Experimental Hydrocephalus Produced by the Subarachnoid Infusion of Silicone Oil. Journal of Neurosurgery, 31, 10-14. https://doi.org/10.3171/jns.1969.31.1.0010

[42] Wisniewski, H. (1961) Research on Experimental Filling of the Ventricular System of Dogs. Acta Neuropathologica, 1, 238-244. https://doi.org/10.1007/BF00687190

[43] Zhao, K., Sun, H., Shan, Y., Mao, B.Y. and Zhang, H. (2010) Cerebrospinal Fluid Absorption Disorder of Arachnoid Villi in a Canine Model of Hydrocephalus. Neurology India, 58, 371-376. https://doi.org/10.4103/0028-3886.65601

[44] Morescalchi, F., Costagliola, C., Duse, S., Gambicorti, E., Parolini, B., Arcidiacono, B., Romano, M.R. and Semeraro, F. (2014) Heavy Silicone Oil and Intraocular Inflammation. BioMed Research International, 2014, Article ID: 574825. 
https://doi.org/10.1155/2014/574825

[45] Brown, J.A., Rachlin, J., Rubin, J.M. and Wollmann, R.L. (1984) Ultrasound Evaluation of Experimental Hydrocephalus in Dogs. Surgical Neurology, 22, 273-276. https://doi.org/10.1016/0090-3019(84)90013-2

[46] Page, L.K. and White, W.P. (1982) Transsphenoidal Injection of Silicone for the Production of Communicating or Obstructive Hydrocephalus in Dogs. Surgical Neurology, 17, 247-250. https://doi.org/10.1016/0090-3019(82)90113-6

[47] Dandy, W.E. and Blackfan, K.D. (1913) An Experimental and Clinical Study of Internal Hydrocephalus. JAMA, 61, 2216-2217. https://doi.org/10.1001/jama.1913.04350260014006

[48] Dandy, W.E. (1919) Experimental Hydrocephalus. Annals of Surgery, 70, 129-142. https://doi.org/10.1097/00000658-191908000-00001

[49] De, S.N. (1950) A Study of the Changes in the Brain in Experimental Internal Hydrocephalus. The Journal of Pathology and Bacteriology, 62, 197-207. https://doi.org/10.1002/path.1700620207

[50] Johnson, M.J., Ayzman, I., Wood, A.S., Tkach, J.A., Klauschie, J., Skarupa, D.J., McAllister, J.P., II and Luciano, M.G. (1999) Development and Characterization of an Adult Model of Obstructive Hydrocephalus. Journal of Neuroscience Methods, 91, 55-65. https://doi.org/10.1016/S0165-0270(99)00072-2

[51] Park, Y.S., Park, S.W., Suk, J.S. and Nam, T.K. (2011) Development of an Acute Obstructive Hydrocephalus Model in Rats Using N-butyl Cyanoacrylate. Childs Nervous System, 27, 903-910. https://doi.org/10.1007/s00381-011-1398-9

[52] Slobodian, I., Krassioukov-Enns, D. and Del Bigio, M.R. (2007) Protein and Synthetic Polymer Injection for Induction of Obstructive Hydrocephalus in Rats. Cerebrospinal Fluid Research, 4, 9. https://doi.org/10.1186/1743-8454-4-9

[53] Di Rocco, C., Pettorossi, V.E., Caldarelli, M., Mancinelli, R. and Velardi, F. (1977) Experimental Hydrocephalus Following Mechanical Increment of Intraventricular Pulse Pressure. Experientia, 33, 1470-1472. https://doi.org/10.1007/BF01918814

[54] Di Rocco, C., Pettorossi, V.E., Caldarelli, M., Mancinelli, R. and Velardi, F. (1978) Communicating Hydrocephalus Induced by Mechanically Increased Amplitude of the Intraventricular Cerebrospinal Fluid Pressure: Experimental Studies. Experimental Neurology, 59, 40-52. https://doi.org/10.1016/0014-4886(78)90199-1

[55] Di Rocco, C., di Tripani, G., Pettorossi, V.E. and Caldarelli, M. (1979) On the Pathology of Experimental Hydrocephalus Induced by Artificial Increase in Endoventricular CSF Pulse Pressure. Childs Brain, 5, 81-95.

[56] Rekate, H.L. (2011) A Consensus on the Classification of Hydrocephalus: Its Utility in the Assessment of Abnormalities of Cerebrospinal Fluid Dynamics. Child s Nervous System, 27, 1535-1541. https://doi.org/10.1007/s00381-011-1558-y

[57] Stempak, J.G. (1964) Etiology of Trypan Blue Induced Antenatal Hydrocephalus in the Albino Rat. The Anatomical Record, 148, 561-571. https://doi.org/10.1002/ar.1091480407

[58] Agnew, W.F., Fauvre, F.M. and Pudenz, P.H. (1968) Tellurium Hydrocephalus: Distribution of Tellurium-127m between Maternal, Fetal, and Neonatal Tissues of the Rats. Experimental Neurology, 21, 120-131. https://doi.org/10.1016/0014-4886(68)90038-1

[59] Duckett, S. (1971) The Morphology of Tellurium-Induced Hydrocephalus. Experimental Neurology, 31, 1-16. https://doi.org/10.1016/0014-4886(71)90172-5

[60] Garro, F. and Pentschew, A. (1964) Neonatal Hydrocephalus in the Offspring of 
Rats Fed during Pregnancy Non-Toxic Amounts of Tellurium. Archiv fur Psychiatrie und Nervenkrankheiten, 206, 272-280. https://doi.org/10.1007/BF00940754

[61] McLone, D.G. (1984) Congenital Hydrocephalus in Mice and Man. In: Kalter, H., Ed., Issues and Reviews in Teratology, Vol. 2, Plenum Press, New York, 67-89. https://doi.org/10.1007/978-1-4615-7314-2_3

[62] Johanson, C.E., Szmydynger Chodobska, J., Chodobski, A., Baird, A., McMillan, P. and Stopa, E.G. (1999) Altered Formation and Bulk Absorption of Cerebrospinal Fluid in FGF-2-Induced Hydrocephalus. American Journal of Physiology, 277, R263-R271.

[63] Pearce, R.K., Collins, P., Jenner, P., Emmett, C. and Marsden, C.D. (1996) Intraventricular Infusion of Basic Fibroblast Growth Factor (bFGF) in the MPTP-Treated Common Marmoset. Synapse, 23, 192-200. https://doi.org/10.1002/(SICI)1098-2396(199607)23:3<192::AID-SYN8>3.0.CO;2-3

[64] Cohen, A.R., Leifer, D.W., Zechel, M., Flaningan, D.P., Lewin, J.S. and Lust, W.D. (1999) Characterization of a Model of Hydrocephalus in Transgenic Mice. Journal of Neurosurgery, 91, 978-988. https://doi.org/10.3171/jns.1999.91.6.0978

[65] Galbreath, E., Kim, S.J., Park, K., Brenner, M. and Messing, A. (1995) Overexpression of TGF-beta 1 in the Central Nervous System of Transgenic Mice Results in Hydrocephalus. Journal of Neuropathology \& Experimental Neurology, 54, 339-349. https://doi.org/10.1097/00005072-199505000-00007

[66] Lacombe, P., Mathews, P.M., Schmidt, S.D., Breidert, T., Heneka, M.T., Landreth, G.E., Feinstein, D.L. and Galea, E. (2004) Effect of Anti-Inflammatory Agents on Transforming Growth Factor Beta Over-Expressing Mouse Brains: A Model Revised. Journal of Neuroinflammation, 1, 11. https://doi.org/10.1186/1742-2094-1-11

[67] Tada, T., Kanaji, M. and Kobayashi, S. (1994) Induction of Communicating Hydrocephalus in Mice by Intrathecal Injection of Human Recombinant Transforming Growth Factor-Beta 1. Journal of Neuroinflammation, 50, 153-158.

[68] Tada, T., Zhan, H., Tanaka, Y., Hongo, K., Matsumoto, K. and Nakamura, T. (2006) Intraventricular Administration of Hepatocyte Growth Factor Treats Mouse Communicating Hydrocephalus Induced by Transforming Growth Factor $\beta 1$. Neurobiology of Disease, 21, 576-586. https://doi.org/10.1016/j.nbd.2005.09.002

[69] Wyss-Coray, T., Feng, L., Masliah, E., Ruppe, M.D., Lee, H.S., Toggas, S.M., Rockenstein, E.M. and Mucke, L. (1995) Increased Central Nervous System Production of Extracellular Matrix Components and Development of Hydrocephalus in Transgenic Mice Overexpressing Transforming Growth Factor-Beta 1. American Journal of Pathology, 147, 53-67.

[70] Dietrich, W.D., Alonso, O., Busto, R. and Finklestein, S.P. (1996) Posttreatment with Intravenous Basic Fibroblast Growth Factor Reduces Histopathological Damage Following Fluid-Percussion Brain Injury in Rats. Journal of Neurotrauma, 13, 309-316.

[71] Wagner, J.P., Black, I.B. and DiCicco-Bloom, E. (1999) Stimulation of Neonatal and Adult Brain Neurogenesis by Subcutaneous Injection of Basic Fibroblast Growth Factor. Journal of Neuroscience, 19, 6006-6016.

[72] Ahn, S.O., Chang, Y.S., Sung, D.K., Sung, S.I., Yoo, H.S., Lee, J.H., Oh, W.I. and Park, W.S. (2013) Mesenchymal Stem Cells Prevent Hydrocephalus after Severe Intraventricular Hemorrhage. Stroke, 44, 497-504. https://doi.org/10.1161/STROKEAHA.112.679092

[73] Ahn, S.O., Chang, Y.S., Sung, D.K., Sung, S.I., Yoo, H.S., Im, G.H., Choi, S.J. and Park, W.S. (2015) Optimal Route for Mesenchymal Stem Cells Transplantation after 
Severe Intraventricular Hemorrhage in Newborn Rats. PLOS ONE, 10, e0132919. https://doi.org/10.1371/journal.pone.0132919

[74] Aquilina, K., Hobbs, C. Tucker, A., Whitelaw, A. and Thoresen, M. (2008) Do Drugs That Block Transforming Growth Factor Beta Reduce Posthaemorrhagic Ventricular Dilatation in a Neonatal Rat Model? Acta Pædiatrica, 97, 1181-1186. https://doi.org/10.1111/j.1651-2227.2008.00903.x

[75] Gao, F., Liu, F., Chen, Z., Hua, Y., Keep, R.F. and Xi, G. (2014) Hydrocephalus after Intraventricular Hemorrhage: The Role of Thrombin. Journal of Cerebral Blood Flow \& Metabolism, 34, 489-494. https://doi.org/10.1038/jcbfm.2013.225

[76] Gao, F., Zheng, M., Hua, Y., Keep, R.F. and Xi, G. (2016) Acetazolamide Attenuates Thrombin-Induced Hydrocephalus. Acta Neurochirurgica Supplement, 121, 373-377. https://doi.org/10.1007/978-3-319-18497-5_64

[77] Meng, H., Li, F., Hu, R., Yuan, Y., Gong, G., Hu, S. and Feng, H. (2015) Deferoxamine Alleviates Chronic Hydrocephalus after Intraventricular Hemorrhage through Iron Chelation and Wnt1/Wnt3a Inhibition. Brain Research, 1602, 44-52. https://doi.org/10.1016/j.brainres.2014.08.039

[78] Zhao, J, Chen, Z., Xi, G., Keep, R.F. and Hua, Y. (2014) Deferoxamine Attenuates Acute Hydrocephalus after Traumatic Brain Injury in Rats. Translational Stroke Research, 5, 586-594. https://doi.org/10.1007/s12975-014-0353-y

[79] Yung, Y.C., Mutoh, T., Lin, M.E., Noguchi, K., Rivera, R.R., Choi, J.W., Kingsbury, M.A. and Chun, J. (2011) Lysophosphatidic Acid Signaling May Initiate Fetal Hydrocephalus. Science Translational Medicine, 3, 99ra87. https://doi.org/10.1126/scitranslmed.3002095

[80] Del Bigio, M.R. (2011) Cell Proliferation in Human Ganglionic Eminence and Suppression after Prematurity-Associated Haemorrhage. Brain, 134, 1344-1361. https://doi.org/10.1093/brain/awr052

[81] Lategan, B., Chodirker, B.N. and Del Bigio, M.R. (2010) Fetal Hydrocephalus Caused by Cryptic Intraventricular Hemorrhage. Brain Pathology, 20, 391-398. https://doi.org/10.1111/j.1750-3639.2009.00293.x

[82] Shaheen, R., Sebai, M.A., Patel, N., Ewida, N., Kurdi, W., Altweijri, I., Sogaty, S., Almardawi, E., Seidahmed, M.Z., Alnemri, A., Madirevula, S., Ibrahim, N., Abdulwahab, F., Hashem, M., Al-Sheddi, T., Alomar, R., Alobeid, E., Sallout, B., AlBaqawi, B., AlAali, W., Ajaji, N., Lesmana, H., Hopkin, R.J., Dupuis, L., Mendoza-Londono, R., Al Rukban, H., Yoon, G., Faqeih, E. and Alkuraya, F.S. (2017) The Genetic Landscape of Familial Congenital Hydrocephalus. Annals of Neurology, 81, 890-897. https://doi.org/10.1002/ana.24964

[83] Jones, H.C. and Bucknall, R.M. (1988) Inherited Prenatal Hydrocephalus in the H-Tx Rat: A Morphological Study. Neuropathology and Applied Neurobiology, 14, 263-274. https://doi.org/10.1111/j.1365-2990.1988.tb00887.x

[84] Kohn, D.F., Chinookoswong, N. and Chou, S.M. (1981) A New Model of Congenital Hydrocephalus in the Rat. Acta Neuropathologicaologica (Berl), 54, 211-218. https://doi.org/10.1007/BF00687744

[85] Jones, H.C., Carter, B.J. and Morel, L. (2003) Characteristics of Hydrocephalus Expression in the LEW/Jms Rat Strain with Inherited Disease. Child s Nervous System, 19, 11-18.

[86] Sasaki, S., Goto, H., Nagano, H., Furuya, K., Omata, Y., Kanazawa, K., Suzuki, K., Sudo, K. and Collmann, H. (1983) Congenital Hydrocephalus Revealed in the Inbred Rat, LEW/Jms. Neurosurgery, 13, 548-554. https://doi.org/10.1227/00006123-198311000-00011 
[87] Mashayekhi, F. (2012) The Importance of Cerebrospinal Fluid in Cerebral Cortical Development. Iranian Journal of Science \& Technology, A4, 493-499.

[88] Mashayekhi, F., Bannister, C.M. and Miyan, J.A. (2000) Possible Role of CSF in a Developmental Abnormality Associated with Early-Onset Hydrocephalus. European Journal of Pediatric Surgery, 10, 39-40.

[89] Mashayekhi, F., Bannister, C.M. and Miyan, J.A. (2001) Failure in Cell Proliferation in the Germinal Epithelium of the Htx Rats. European Journal of Pediatric Surgery, 11, 557-559.

[90] Mashayekhi, F., Draper, C.E., Bannister, C.M., Pourghasem, M., Owen-Lynch, P.J. and Miyan, J.A. (2002) Deficient Cortical Development in the Hydrocephalic Texas (H-Tx) Rat: A Role for CSF. Brain, 125, 1859-1874. https://doi.org/10.1093/brain/awf182

[91] Miyan, J.A., Khan, M.I., Kawarada, Y., Sugiyama, T. and Bannister, C.M. (1998) Cell Death in the Brain of the HTx Rat. European Journal of Pediatric Surgery, 8 , 43-48. https://doi.org/10.1055/s-2008-1071253

[92] Owen-Lynch, P.J., Draper, C.E., Mashayekhi, F., Bannister, C.M. and Miyan, J.A. (2003) Defective Cell Cycle Control Underlies Abnormal Cortical Development in the Hydrocephalic Texas Rat. Brain, 126, 623-631.

https://doi.org/10.1093/brain/awg058

[93] Vetsika, E.K., Bannister, C.M., Buckle, A.M. and Miyan, J.A. (1999) The Effects of CSF Blockage in Early-Onset Hydrocephalus on the Activity of the Germinal Epithelium. European Journal of Pediatric Surgery, 9, 43-44.

[94] Jones, H.C., Harris, N.G., Rocca, J.R. and Andersohn, R.W. (2000a) Progressive Tissue Injury in Infantile Hydrocephalus and Prevention/Reversal with Shunt Treatment. Neurological Research, 22, 89-96. https://doi.org/10.1080/01616412.2000.11741041

[95] Cains, S., Shepherd, A., Nabiuni, M., Owen-Lynch, P.J. and Miyan, J. (2009) Addressing a Folate Imbalance in Fetal Cerebrospinal Fluid Can Decrease the Incidence of Congenital Hydrocephalus. Journal of Neuropathology \& Experimental Neurology, 68, 404-416. https://doi.org/10.1097/NEN.0b013e31819e64a7

[96] Cai, X., McGraw, G., Pattisapu, J.V., von Kalm, L., Willingham, S., Socci, D. and Gibson, J.S. (2000) Hydrocephalus in the H-Tx Rat: A Monogenic Disease? Experimental Neurology, 163, 131-135. https://doi.org/10.1006/exnr.1999.7301

[97] Jones, H.C., Lopman, B.A., Jones, T.W., Carter, B.J., Depelteau, J.S. and Morel, L. (2000b) The Expression of Inherited Hydrocephalus in H-Tx Rats. Child s Nervous System, 16, 578-584. https://doi.org/10.1007/s003810000330

[98] Jones, H.C., Carter, B.J., Depelteau, J.S., Roman, M. and Morel, L. (2001) Chromosomal Linkage Associated with Disease Severity in the Hydrocephalic H-Tx Rat. Behavior Genetics, 31, 101-111. https://doi.org/10.1023/A:1010266110762

[99] Hawkins, D., Bowers, T.M., Bannister, C.M. and Miyan, J.A. (1997) The Functional Outcome of Shunting H-Tx Rat Pups at Different Ages. European Journal of Pediatric Surgery, 7, 31-34. https://doi.org/10.1055/s-2008-1071206

[100] Dahme, M., Bartsch, U., Martini, R., Anliker, B., Schachner, M. and Mantel, N. (1997) Disruption of the Mouse L1 Gene Leads to Malformations of the Nervous System. Nature Genetics, 17, 346-349. https://doi.org/10.1038/ng1197-346

[101] Demyanenko, G.P., Tsai, A.Y. and Maness, P.F. (1999) Abnormalities in Neuronal Process Extension, Hippocampal Development, and the Ventricular System of L1 Knockout Mice. Journal of Neuroscience, 19, 4907-4920.

[102] Gruneberg, H. (1943) Congenital Hydrocephalus in the Mouse; A Case of Spurious 
Pleiotropism. Journal of Genetics, 45, 1-21. https://doi.org/10.1007/BF02982770

[103] Berry, R.J. (1961) The Inheritance and Pathogenesis of Hydrocephalus-3 in the Mouse. The Journal of Pathology and Bacteriology, 81, 157-167. https://doi.org/10.1002/path.1700810119

[104] Lawson, R.F. and Raimondi, A.J. (1973) Hydrocephalus-3, a Murine Mutant: I. Alterations in Fine Structure of Choroid Plexus and Ependyma. Surgical Neurology, 1, 115-128.

[105] Davy, B.E. and Robinson, M.L. (2003) Congenital Hydrocephalus in hy3 Mice Is Caused by a Frameshift Mutation in Hydin, a Large Novel Gene. Human Molecular Genetics, 12, 1163-1170. https://doi.org/10.1093/hmg/ddg122

[106] Dawe, H.R., Shaw, M.K., Farr, H. and Gull, K. (2007) The Hydrocephalus Inducing Gene Product, Hydin, Positions Axonemal Central Pair Microtubules. BMC Biology, 5, 33. https://doi.org/10.1186/1741-7007-5-33

[107] Bronson, R.T. and Lane, P.W. (1990) Hydrocephalus with Hop Gait (hyh): A New Mutation on Chromosome 7 in the Mouse. Brain Research. Developmental Brain Research, 54, 131-136. https://doi.org/10.1016/0165-3806(90)90073-8

[108] Chae, T.H., Kim, S., Marz, K.E., Hanson, P.I. and Walsh, C.A. (2004) The hyh Mutation Uncovers Roles for Alpha Snap in Apical Protein Localization and Control of Neural Cell Fate. Nature Genetics, 36, 264-270. https://doi.org/10.1038/ng1302

[109] Hong, H.K., Chakravarti, A. and Takahashi, J.S. (2004) The Gene for Soluble N-Ethylmaleimide Sensitive Factor Attachment Protein Alpha Is Mutated in Hydrocephaly with Hop Gait (hyh) Mice. Proceedings of the National Academy of Sciences, 101, 1748-1753. https://doi.org/10.1073/pnas.0308268100

[110] Jiménez, A.J., García-Verdugo, J.M., González, C.A., Bátiz, L.F., Rodríguez-Pérez, L.M., Páez, P., Soriano-Navarro, M., Roales-Buján, R., Rivera, P., Rodríguez, S., Rodríguez, E.M. and Pérez-Fígares, J.M. (2009) Disruption of the Neurogenic Niche in the Subventricular Zone of Postnatal Hydrocephalic hyh Mice. Journal of Neuropathology \& Experimental Neurology, 68, 1006-1020. https://doi.org/10.1097/NEN.0b013e3181b44a5a

[111] Bruni, J.E., Del Bigio, M.R., Cardoso, E.R. and Persaud, T.V.N. (1988a) Neuropathology of Congenital Hydrocephalus in the SUMS/NP Mouse. Acta Neurochirurgica (Wien), 92, 118-122. https://doi.org/10.1007/BF01401981

[112] Jones, H.C., Dack S. and Ellis, C. (1987) Morphological Aspects of the Development of Hydrocephalus in a Mouse Mutant (SUMS/NP). Acta Neuropathologicaologica, 72, 268-276. https://doi.org/10.1007/BF00691100

[113] Bryan, J.H.D., Hughes, R.L. and Bates, T.J. (1977) Brain Development in the Hydrocephalic-Polydactyl, a Recessive Pleiotropic Mutant in the Mouse. Virchows Archiv A, 374, 205-214. https://doi.org/10.1007/BF00427115

[114] Hollander, W.F. (1976) Hydrocephalic-Polydactyl, a Recessive Pleiotropic Mutant in the Mouse, and Its Location in Chromosome 6. Iowa State Journal of Research, 51, 13-23.

[115] Kume, T., Deng, K.Y., Winfrey, V., Gould, D.B., Walter, M.A. and Hogan, B.L. (1998) The Forkhead/Winged Helix Gene Mf1 Is Disrupted in the Pleiotropic Mouse Mutation Congenital Hydrocephalus. Cell, 93, 985-996. https://doi.org/10.1016/S0092-8674(00)81204-0

[116] Hollander, W.F. (1966) Hydrocephalic-Polydactyl, a Recessive Pleiotropic Mutant in the Mouse. American Zoologist, 6, 588-589.

[117] Bruni, J.E., Del Bigio, M.R., Cardoso, E.R. and Persaud, T.V.N. (1988b) Hereditary 
Hydrocephalus in Laboratory Animals and Humans. Journal of Experimental Pathology, 35, 239-249. https://doi.org/10.1016/S0232-1513(88)80094-X

[118] McMullen, A.B., Baidwan, G.S. and McCarthy, K.D. (2012) Morphological and Behavioral Changes in the Pathogenesis of a Novel Mouse Model of Communicating Hydrocephalus. PLOS ONE, 7, e30159.

https://doi.org/10.1371/journal.pone.0030159

[119] Sweger, E.J., Casper, K.B., Scearce-Levie, K., Conklin, B.R. and McCarthy, K.D. (2007) Development of Hydrocephalus in Mice Expressing the G1-Coupled GPCR Ro1 RASSL Receptor in Astrocytes. Journal of Neuroscience, 27, 2309-2317. https://doi.org/10.1523/JNEUROSCI.4565-06.2007

[120] McAllister, J.P., II (2012) Pathophysiology of Congenital and Neonatal Hydrocephalus. Seminars in Fetal \& Neonatal Medicine, 17, 285-294.

https://doi.org/10.1016/j.siny.2012.06.004

\section{Abbrevations}

CSF-cerebrospinal fluid

FGF-fibroblast growth factor

GE-germinal epithelium

GFAP_-glial fibrillary acidic protein

$\mathrm{H}$-Tx-hydrocephalus Texas

hpy-hydrocephalus associated with polydactyly

hy-3-hydrocephalus-3

hyh-hydrocephalus with hop gait

L1 CAM-L1 cell adhesion molecule

LPA-lysophosphatidic acid

Napa $\alpha$-SNAP-N-ethylmalemide-sensitive factor (NSF) attachment protein alpha-S-nitroso-N-acetylpenicillamine

NPCs-neuronal progenitors cells

RASSL-receptor activated solely by synthetic ligands

SVZ-subventricular zone

TGF- $\beta 1$-transforming growth factor-beta 1

tTA-tet-transactivator 